\title{
Who are the Job Seekers? Explaining Unemployment among Doctoral Recipients
}

\author{
Mara Yerkes \\ Institute for Social Science Research, University of Queensland \\ Brisbane, Australia, and \\ Erasmus University Rotterdam, Rotterdam, the Netherlands \\ m.yerkes@uq.edu.au \\ Rens van de Schoot \\ Department of Methods and \\ Statistics, \\ Utrecht University, \\ Utrecht, the Netherlands \\ a.g.j.vandeschoot@uu.nl \\ Hans Sonneveld \\ Netherlands Centre for \\ Graduate and Research \\ Schools, Utrecht University, \\ Utrecht, the Netherlands \\ j.f.m.sonneveld@uu.nl
}

This project was financed by the Dutch Ministry of Education, Culture and Science and IVLOS at Utrecht University.

\begin{abstract}
Despite increased attention for doctoral education in recent years, one particular phenomenon has received little attention - the unemployment of doctoral candidates following graduation. While the unemployment of doctoral recipients is relatively low in comparison to the general population, the absence of empirical studies means possible important patterns are being overlooked. Using survey data from four universities in the Netherlands, we investigate unemployment among recent doctoral graduates. By comparing the job seekers to employed doctoral recipients and focusing on both structural and individual level variables, including demographic characteristics, previous research experience, job seeking activities, and differences in the $\mathrm{PhD}$ trajectory, we are able to discern a number of shared characteristics among the job seekers. Our findings suggest that unemployment among doctoral candidates is not random or evenly distributed. In contrast to the general population, where socio structural characteristics such as educational level and gender are integral in explaining unemployment, within this level of educational attainment primarily individual level factors are more salient in explaining unemployment among this group of job seekers.
\end{abstract}

Key words: academic performance, job seekers, doctoral education, unemployment

Material published as part of this publication, either on-line or in print, is copyrighted by the Informing Science Institute. Permission to make digital or paper copy of part or all of these works for personal or classroom use is granted without fee provided that the copies are not made or distributed for profit or commercial advantage AND that copies 1) bear this notice in full and 2) give the full citation on the first page. It is permissible to abstract these works so long as credit is given. To copy in all other cases or to republish or to post on a server or to redistribute to lists requires specific permission and payment of a fee. Contact Publisher@InformingScience.org to request redistribution permission.

\section{Introduction}

There has been increased attention for issues specific to doctoral education in recent years, with analyses that focus on doctoral training (Bleiklie \& Høstaker, 2004; Enders \& de Weert, 2004) or stages of the doctoral trajectory (Grover, 2007), academic employment and mobility (Enders, 2001; Huisman, de 
Weert, \& Bartelse, 2002; Musselin, 2004) and studies that focus on structural inequalities, such as gender differences (England et al., 2007; Mastekaasa, 2005; NRC, 2010). Several studies are also available that address doctoral education across specific disciplines, such as science and engineering (Lee, Miozzo, \& Laredo, 2010), economics (Siegfried \& Stock, 1999), history (Brailsford, 2010; Sclater, Rudd, Morrison, Picciano, \& Nerad, 2008), the biomedical sciences (Knobil, 1996) or sociology (Dotzler \& Koppel, 1999). In addition, there has been increased attention at the international level for the need for more detailed data and cross-country comparisons of doctoral education outcomes, as organisations such as the Organisation for Economic Cooperation and Development (OECD), the United Nations Educational, Scientific and Cultural Organisation (UNESCO) and the European Union's statistical organisation EUROSTAT have pushed for an internationally coordinated collection of data on doctoral recipients (EUROSTAT / UNESCO / OECD, 2006). A phenomenon that has received decidedly less attention is the unemployment of doctoral recipients, which is the focus of this article.

Given the low rate of unemployment among doctoral holders (Eurostat, 2006), the absence of studies in this area seems unsurprising. A small number of older studies can be found in this area, for example, a study about higher unemployment rates among doctoral holders during the recession of the 1980s (Tuckman \& Tuckman, 1984) or perceived dissatisfaction in finding employment after obtaining a $\mathrm{PhD}$ (Stoneman, 1997). More recent studies remain absent. Again, this may seem unsurprising. Unemployment among doctoral holders is much lower than unemployment in the general population (Eurostat, 2006; Organisation for Economic Co-operation and Development, 2011; Stoneman, 1997). In addition, doctoral holders have significant labour market advantages as a result of their education and training in comparison to unemployed individuals who lack secondary or tertiary educational qualifications. However, the lack of attention for this phenomenon means that important patterns can be overlooked. In this article, we take a closer look at these unemployed doctoral graduates in the Netherlands, explaining a much under-studied phenomenon. The participants in our study were approached at the moment of registering for the $\mathrm{PhD}$ defence and have, therefore, not yet officially received their doctorate degree. While one could argue they are not doctoral recipients per se, given the structure of the Dutch doctoral education system, it is possible for us to refer to candidates registered for the defence as doctoral recipients. We provide a full explanation of this assumption in the methodology section. We introduce our data and methodology before moving on to a descriptive analysis of employment and unemployment among Dutch doctoral recipients. Following, we put the spotlight on the job seekers, those doctoral recipients who did not have a job at the time of graduation but are seeking employment. In the final section, we discuss the broader applicability of these results for other countries and make some suggestions for further research.

\section{Data and Methodology}

We rely on survey data about Dutch doctoral recipients gathered between February 2008 and June 2009 in the Netherlands at four universities. Respondents were approached after registering for the doctoral defence through the university office in charge of organising the doctoral defence. Following registration, we e-mailed possible respondents and invited them to participate in the survey. Respondents were approached a maximum of three times, including reminder e-mails. The four universities where data were gathered include Delft University of Technology, Erasmus University Rotterdam, Utrecht University, and Wageningen University and Research Centre. These four universities were used because they are representative of the broader variety of universities in the Netherlands, including a younger university with a more limited disciplinary agenda (Rotterdam), a university focused on the agricultural sciences (Wageningen), a more traditional university with a broad disciplinary agenda (Utrecht), and a university focused on the technical sciences (Delft). All information gathered in this survey, including respondents' e-mail 
addresses remains confidential; any identifying information has been removed for purposes of confidentiality.

A total of 565 respondents completed the survey. A brief descriptive overview of the data reveals that a large proportion of respondents obtained their doctorate degree either in the Natural Sciences $(31 \%)$ or in the Medical and Health Sciences (25\%). A further 16 per cent of respondents obtained their doctorate in the Social Sciences, 15 per cent in Engineering and Technology, 7 per cent in Agricultural Sciences, and 6 per cent in the Humanities. Slightly less than half of doctoral recipients surveyed were female $(47 \%)$. The mean age of our respondents was 34 years old. The majority of doctoral recipients were between the ages of 25 and 40 when completing their degree, but some graduates were over the age of 40 when reaching the completion stage of their doctorate (10 per cent; ten graduates were over the age of 65). Two-thirds of our respondents reported being born in the Netherlands (67\%). Doctoral recipients born outside the Netherlands were most often born in other Western European countries, Asian countries, or Eastern European countries. Less than five per cent of the doctoral recipients we surveyed are from North America, Latin and South America, or Africa.

Of the 565 respondents who completed the survey, approximately 11 per cent stopped filling in the questionnaire prior to reaching the final section of the survey. In the analyses in this article, we use all available information about our respondents. No data have been imputed through missing analysis for this information, which is why the sample size does not equal 565 for some of the analyses. Following a descriptive analysis, where we look at the employment status of doctoral candidates when they register for the defence and at the reasons given for being unemployed, we look more closely at the job seekers, of which there are 44 in our analysis. What explains their status as unemployed and seeking employment? Are there social structural differences between the employed and the job seekers, such as gender differences? Or can these differences be explained by differences in individual $\mathrm{PhD}$ trajectories, such as achievements during the $\mathrm{PhD}$ ?

We consider both structural and individual level variables across four areas: demographic characteristics (including gender, age, country of birth/citizenship, marital status and the presence of children in the household), previous research experience, job seeking activities, and the PhD trajectory. The latter includes variables on $\mathrm{PhD}$ status, field of study, performance during the $\mathrm{PhD}$, expectations during the $\mathrm{PhD}$ trajectory, and the quality of $\mathrm{PhD}$ supervision. We analyse the job seekers in relation to job holders across these four groupings of variables. Given the small size of the group of job seekers, we report all statistics. Where multivariate analyses have been carried out, we corrected for capitalization of chance using the Wilks' Lambda statistic.

Dutch doctoral candidates are not classified as students. In contrast, $\mathrm{PhD}$ status can take on three different forms in the Netherlands, differences that are particularly relevant when looking at the transition to employment: (a) $\mathrm{PhD}$ candidates employed by the university,(b) scholarship recipients, and (c) external and/or dual $\mathrm{PhD}$ candidates. The majority of $\mathrm{PhD}$ candidates in our survey $(71 \%)$ are employed by the university and have an employment contract for a specified duration, with working conditions and salary regulated by the collective agreement covering the Association of Universities in the Netherlands (see www.vsnu.nl for more information). These employment contracts can be either full-time or part-time in theory; in reality, respondents are employed with the university for an average of 38 hours a week. Scholarship recipients do not have an employment contract. Rather, they have a scholarship or stipend for a specified period of time. Scholarship recipients make up only 5 per cent of our sample. Lastly, external and/or dual PhD candidates, often not accounted for in studies on doctoral education in the Netherlands, are a mixture of different candidates who do not have a formal full-time employment contract of 1.0FTE or $0.8 \mathrm{FTE}$ at the university or a scholarship or stipend. Their status can take on different forms; for example, an external candidate who works part-time on his or her thesis while having a job elsewhere or dual candidates, such as junior lecturers, who work part-time at a university while work- 
ing part-time on their $\mathrm{PhD}$ thesis. In our survey, 24 per cent of respondents were external candidates, including a very small number of respondents who worked on a $\mathrm{PhD}$ thesis during retirement.

The participants in our study have not yet officially received their doctorate degree and are, therefore, not doctoral recipients per se. However, we refer to the respondents as doctoral recipients given the structure of the Dutch system. Firstly, doctoral candidates who have registered for their defence in the Netherlands are not similar to ABD candidates in the US and elsewhere. The term $\mathrm{ABD}$ does not exist in the Dutch system if someone has registered for the defence. By definition, someone who registers for their defence has had official approval from the defence committee for their thesis. The defence itself is primarily ceremonial. While in theory the committee could choose not to confer the degree, in reality this would only happen in exception cases, such as fraud. Only two such cases have been publicly reported in the past six years (Kolfschooten, 2006, 2007).

Secondly, the structure of the Dutch doctoral system, with varying PhD status as described above, means the majority of doctoral candidates are employees of the university. These candidates are most often employed as full-time researchers and are not equivalent to $\mathrm{PhD}$ students in other countries, as they have greater rights and benefits. Nor are they considered to be graduate assistants or research assistants; rather, their employment is considered equivalent to that of a researcher.

Therefore, we refer to our respondents as doctoral recipients throughout the article. We realize that this has consequences for the way in which we view the employment status of doctoral recipients. While we cannot directly infer whether their employment status changed immediately following the defence or within 12 months of the defence, respondents were asked whether they expected to still be in the same job six months following the defence. Of the 396 employed respondents who answered this question, 70 per cent felt they would still be in this job six months later. While the timing of employment (at the moment of defence, or one to two years following the defence) is crucial given this context in which, in the Netherlands, nearly three-fourths of the doctoral candidates are employed as researchers by universities and the intent of most candidates is to remain in the same job for the next 6 months, we can use the data on employment status at the time of defence to say something meaningful about initial employment opportunities for doctoral recipients in the Netherlands. Moreover, we refer to a limited number of national statistics on the employment status of doctorate holders in the Netherlands to support our conclusions. We do note, however, that the employment situation may change for these individuals within one to two years following graduation, and further study of these individuals is needed. In addition, we recognize that the situation for external candidates may be quite different, pointing to the need for more detailed research on this specific group of doctoral candidates (Gardner \& Gopaul, 2012).

The field of study for our respondents is broken down into six categories: Agricultural Sciences, Engineering and Technology, the Humanities, the Medical and Health Sciences, the Natural Sciences, and the Social Sciences. We look at eight separate characteristics of academic performance; these are the number of:

1. papers (co)authored and presented at regional, national or international conferences

2. posters presented at national and international conferences

3. articles (co)authored and submitted to an international, scientific journal

4. articles (co)authored and accepted in an international, scientific journal

5. books or monographs (co)authored that have been published or accepted for publication 
6. book chapters or other publications (co)authored that have been published or accepted for publication

7. external reports (co)authored that have been published or accepted for publication

8. attendance at professional meetings or conferences

In the original survey, we also included patents applied for, patents granted, and patents granted resulting in a commercial product or process. However, these occur so rarely in the data that they are not included here. For more information on this, see Sonneveld, Yerkes, and van de Schoot (2010). Lastly, we include scales measuring expectations during the $\mathrm{PhD}$ trajectory and $\mathrm{PhD}$ supervision. These scales were created using confirmative factor analysis in Mplus, creating a total of nine scales based on correlations among 29 Likert statements asked of respondents during the survey. These statements contained information on $\mathrm{PhD}$ supervision, the $\mathrm{PhD}$ programme, and labour market preparation, and respondents were asked to answer these statements using a fivepoint scale varying from strongly disagree to strongly agree. For a detailed discussion of these scales see Sonneveld et al. (2010).

\section{Unemployment among Doctoral Recipients}

In the general population, an important predictor of unemployment is educational attainment. Unemployment is a much smaller risk for highly educated individuals, in particular doctoral recipients, where unemployment rates are generally less than three per cent (Eurostat, 2006). The recent global financial crisis may change this to some extent, particularly in countries like the US and the UK, where academic hires seem greatly affected by the loss in university funding, or in countries with extremely high levels of unemployment, such as Spain, where such high levels of unemployment can begin to permeate all levels of the population. As the global financial crisis continues to cause economic uncertainty, even countries like the Netherlands, with one of the lowest registered unemployment rate in Europe, are witnessing significant cuts in academic funding and grant money, which could affect unemployment levels among doctoral recipients in the coming years. Generally speaking, however, until now unemployment among doctoral recipients has been low and employment rates have been high. According to Statistics Netherlands (2011b), 1.4 per cent of doctorate holders in the Netherlands were unemployed as of 2009 and 3.5 per cent of doctorate holders were not active in the labour market (neither employed nor seeking employment).

Data from our study, while confirming that there is a high rate of employment among doctoral recipients, provides a more nuanced view of employment and unemployment at the time of graduation. At the moment of registering for the defence, 86 per cent of Dutch doctoral recipients are already employed (see Table 1). Employment is defined here as paid work at the moment of the defence, including full-time, part-time, or self-employment, as well as employment within or outside one's own field. These results are similar to earlier Dutch data from Hulshof, Verrijt, and Kruijthof (1996), which demonstrate that unemployment has remained unproblematic for most doctoral recipients. We do note, however, that one of the issues raised by Hulshof and colleagues was not concerned with unemployment directly following graduation, but rather with the labour market position of doctoral recipients some years following graduation. The timing of employment under consideration, and in particular whether or not doctoral recipients transition into stable employment in the long-term, remains an important issue for further research. Although most respondents were employed by the time of their defence, 11.9 per cent of respondents were not employed at this time. That is, nine per cent of respondents are not working but are actively seeking a job $(n=44)$, three per cent of respondents are not seeking a job, and two per cent responded "don't know." 84 per cent of employed respondents are working full-time (35 or more hours a week), 13 per cent are working part-time (less than 35 hours a week), and 3 per cent of respon- 
dents hold multiple jobs (either full-time or part-time or a combination thereof). Part-time work is common in the Netherlands and highly protected, in contrast to most other countries (Yerkes \& Visser, 2006). However, 30 per cent of doctoral candidates working part-time reported they were seeking full-time employment. Of the 347 respondents employed full-time, 11 per cent are seeking a different job at the moment of the defence. National statistics suggest that, overall, doctorate holders in the Netherlands are unlikely to work part-time. They report that 7.6 per cent of doctorate holders work part-time, measured as less than 30 hours a week. If we use the same measure, our data show a slightly lower percentage of part-time work at 5.9 per cent. However, this supports evidence from Statistics Netherlands (2011a) that "the share of part-time workers rises with the age of the doctorate holder: only about 5 percent of those younger than 35 work part-time while over 15 percent of doctorate holders older than 54 years are part-time employees". Lastly, as noted above, of the 396 employed respondents who responded to the question, 70 per cent intend to be employed in the same job after receiving their doctorate degree.

Table 1: Employment Status by PhD Status (n=478)

\begin{tabular}{lllll}
\hline & Employee & $\begin{array}{l}\text { Scholarship } \\
\text { recipient }\end{array}$ & $\begin{array}{l}\text { External PhD } \\
\text { candidate }\end{array}$ & Total \\
\hline $\begin{array}{l}\text { Working full-time, or have/had } \\
\text { accepted a full-time job offer }\end{array}$ & $220(64.5)$ & $16(61.5)$ & $73(65.8)$ & $309(64.6)$ \\
$\begin{array}{l}\text { Working full-time but seeking a } \\
\text { different job }\end{array}$ & $28(8.2)$ & $3(11.5)$ & $7(6.3)$ & $38(7.9)$ \\
$\begin{array}{l}\text { Working part-time but seeking full- } \\
\text { time work }\end{array}$ & $12(3.5)$ & $0(0.0)$ & $4(3.6)$ & $16(3.3)$ \\
$\begin{array}{l}\text { Working part-time but NOT seeking } \\
\text { full-time work }\end{array}$ & $24(7.0)$ & $0(0.0)$ & $13(11.7)$ & $37(7.7)$ \\
$\begin{array}{l}\text { Working full-time or part-time in } \\
\text { more than one job }\end{array}$ & $7(2.1)$ & $1(3.8)$ & $3(2.7)$ & $11(2.3)$ \\
$\begin{array}{l}\text { Not working but seeking full-time } \\
\text { work only }\end{array}$ & $22(6.5)$ & $2(7.7)$ & $1(0.9)$ & $25(5.2)$ \\
$\begin{array}{l}\text { Not working but seeking part-time } \\
\text { work only }\end{array}$ & $1(0.3)$ & $0(0.0)$ & $1(0.9)$ & $2(0.4)$ \\
$\begin{array}{l}\text { Not working but seeking any work } \\
\text { (Full-time or part-time) }\end{array}$ & $15(4.4)$ & $0(0.0)$ & $2(1.8)$ & $17(3.6)$ \\
$\begin{array}{l}\text { Not working and unavailable for study } \\
\text { or paid work }\end{array}$ & $4(1.2)$ & $0(0.0)$ & $0(0.0)$ & $4(0.8)$ \\
$\begin{array}{l}\text { Not working and unavailable for paid } \\
\text { work }\end{array}$ & $2(0.6)$ & $2(7.7)$ & $5(4.5)$ & $9(1.9)$ \\
$\begin{array}{l}\text { Don't know } \\
\text { Total }\end{array}$ & $6(1.8)$ & $2(7.7)$ & $2(1.8)$ & $10(2.1)$ \\
\hline
\end{tabular}

Table 2 shows the various reasons given by respondents for not working at the moment of the defence ( $\mathrm{n}=56$; 1 respondent did not answer the follow-up question.) The table includes both respondents seeking employment (the unemployed) and respondents not seeking employment (the non-employed). As we can see from the table, the reason given most often (13 respondents) is that no suitable job is available. Of the 44 respondents who are seeking work (the unemployed), 17 cannot find a suitable job, six respondents are starting a job later in the year and six report not wanting to work. The respondents who answered "other" were most often still looking for a job, 
wanted to wait until the $\mathrm{PhD}$ was fully finished, or were planning on travelling for some period before looking for employment.

Table 2: Reasons for Not Working at the Moment of the PhD Defence $(n=56)$

\begin{tabular}{ll}
\hline Reason & Number (Percentage) \\
\hline Suitable job not available & $18(32.1)$ \\
Other & $13(23.2)$ \\
Starting a new job at later date & $9(16.1)$ \\
Did not need or want to work & $7(12.5)$ \\
Retired & $3(5.4)$ \\
Laid off from a job & $2(3.6)$ \\
Student & $2(3.6)$ \\
Family responsibilities & $1(1.8)$ \\
Chronic illness or permanent disability & $1(1.8)$ \\
Total & $56(100.0)$ \\
\hline
\end{tabular}

We now look to see if the 44 unemployed respondents share any specific characteristics that might help us better understand the labour market position of this group. Put differently, is there a relationship between individual characteristics of doctoral recipients or their $\mathrm{PhD}$ trajectories and their labour market status at the time of the defence (as job seekers)? We start by looking at the relationship between unemployment and a number of demographic characteristics known to affect employment and unemployment in the general population. Following this, we consider a possible relationship between having previous research experience and being unemployed at the time of the defence. Lastly, we investigate any possible differences in the $\mathrm{PhD}$ trajectory, including academic performance, between the job seekers and employed doctoral candidates.

\section{Demographic Characteristics}

We start our investigation of the job seekers by looking at three demographic characteristics known to generate variation in employment and unemployment statistics in the general population: gender, age, and country of birth. 42 of the 44 job seekers provided responses to these demographic questions. From this information we learn that 22 of the job seekers are female and 20 are male, a near fifty-fifty distribution and similar to the general gender distribution in the sample of respondents in our survey $\left(\chi^{2}=0.61, \mathrm{p}=.43\right)$. Therefore, no significant gender differences are found. The mean age of job-seeking doctoral recipients is 33 years old, just one year younger, on average, than the overall mean age of doctoral candidates surveyed. However, this difference is negligible and statistically insignificant $(\mathrm{t}=0.15, \mathrm{p}=.69)$.

There is also a fifty-fifty representation of job seeking doctoral recipients born outside the Netherlands and those born in the Netherlands (21 versus 21 ). In the total population of our survey, the percentage of doctoral recipients born outside the Netherlands is 33 per cent; 67 per cent were born in the Netherlands. In other words, there is a slight overrepresentation of doctoral recipients born outside the Netherlands in the job seekers category $\left(\chi^{2}=6.74, p=.01\right)$. This slight overrepresentation remains even if we account for citizenship as well as country of birth $\left(\chi^{2}=2.84, p=.09\right)$. The data show that 26 of the job seeking respondents $(62 \%)$ were either born in the Netherlands or have a Dutch passport; this holds true for 73 per cent of the sample as a whole.

We also find a number of interesting differences between employed and unemployed doctoral recipients in relation to their marital and family status. Job seekers are less likely to have a partner in comparison to employed doctoral recipients. 29 per cent of job seekers are not married or cohabitating, compared to their employed peers, of which $93 \%$ do have a partner. This difference is 
significant $\left(\chi^{2}=4.21, \mathrm{p}=.04\right)$. We also see a small significant difference between those candidates who do or do not have children in relation to unemployment $\left(\chi^{2}=3.41, p=.04\right)$. Job seekers are less likely to have children in comparison to employed doctoral recipients. 28 per cent of employed respondents have a child; only 14 per cent of respondents report having children. Job seeking doctoral recipients with children or married/cohabitating respondents may be more likely to accept a job that may or may not match their employment preferences to avoid the uncertainty of job seeking, although further research is needed to determine the validity of such an argument.

\section{Previous Research Experience}

Alongside demographic characteristics, we examined the possibility of a relationship between previous work experience and unemployment. We find no association between whether someone previously worked as a researcher before starting the $\mathrm{PhD}$ and being a job seeker. Of the 24 jobseeking respondents who answered the question, 13 of them report having worked as a researcher earlier in their career while $11 \operatorname{did} \operatorname{not}\left(\chi^{2}=0.66, p=.42\right)$.

\section{Job Seeking Activity}

We asked respondents whether they actively looked for a job during the final year of their $\mathrm{PhD}$ trajectory. Not surprisingly, job seeking activity is significantly related to employment at the time of the defence. 36 per cent of employed doctoral recipients actively sought a job during the final year of their PhD trajectory. Among the job seekers, this percentage was much lower $(11 \%)$, revealing a significant difference between these two groups $\left(\chi^{2}=11.00, p=.001\right)$.

\section{Relationship with the PhD Trajectory}

Lastly, we investigate a number of possible relationships between the PhD trajectory and being a job seeker. We looked at the following: $\mathrm{PhD}$ status, field of study, performance during the $\mathrm{PhD}$ (publications, conference presentations, patents, etc.), expectations during the $\mathrm{PhD}$ trajectory, and the quality of $\mathrm{PhD}$ supervision. We also examined the possibility of a relationship between job seekers and the phenomenon of brain drain/brain gain. There is a slight overrepresentation of respondents who came to the Netherlands to obtain a $\mathrm{PhD}$ and who are seeking a job $\left(\chi^{2}=5.64\right.$, $\mathrm{p}=.069)$ ). 33 per cent (14) of job seekers originally came to the Netherlands to obtain a $\mathrm{PhD}$, whereas 20 per cent (75) of $\mathrm{PhD}$ candidates employed at the time of graduation came to the Netherlands to obtain a PhD. We find no relationship between being a job seeker and planning on leaving the Netherlands following graduation $\left(\chi^{2}=2.07, \mathrm{p}=.35\right)$. We also find no difference between the unemployed and the employed in regards to perceived expectations during the $\mathrm{PhD}$ trajectory, including individual expectations, perceived supervisor expectations, and perceived university expectations (Wilks' Lambda $=0.99, \mathrm{p}=.48$ ). Furthermore, an examination of the relationship between the quality of supervision and the quality of the $\mathrm{PhD}$ programme and being a job seeker shows no significant relationship between any of these aspects (Wilks' Lambda $=0.97$, $\mathrm{p}=.51$ ). Naturally, the absence of a significant effect does not mean a relationship does not exist between the quality of supervision and/or the quality of the $\mathrm{PhD}$ programme and employment outcomes. It does, however, mean no relationship can be found between the scales measuring various aspects of the quality of supervision and the quality of the programme and being a job seeker. Research into the relationship between $\mathrm{PhD}$ supervision and postdocs demonstrates, for example, that quality supervision leads to a more positive postdoctoral experience (Scaffidi \& Berman, 2011).

However, we do find a number of interesting factors related to unemployment, including field of study and $\mathrm{PhD}$ performance, which we now explore. When we look at the distribution of job seekers across the three PhD statuses, discussed in the methods section, we find that 38 of the 44 job seekers were employees of the university during their $\mathrm{PhD}$ trajectory. The nominal duration 
of the employment contract is four years, within which time it is expected that the candidate will undertake independent research, write the thesis (and/or a series of articles), and defend. $\mathrm{PhD}$ candidates who were employed on a university contract during the PhD trajectory are more likely to be unemployed than doctoral recipients who were not employees of the university $\left(\chi^{2}=4.81\right.$, $\mathrm{p}=.03$ ). Looking at the relationship between unemployment and field of study, we find a greater proportion of unemployed in the Natural Sciences. 20 of the 44 respondents who report being unemployed but seeking a job come from the Natural Sciences. However, we need to correct for the fact that there are, in general, more respondents in the Natural Sciences in our survey. Thirty per cent of all respondents received their doctorate in the Natural Sciences, a higher proportion than in the other five fields. Despite this, we still see an overrepresentation of doctoral candidates from the Natural Sciences in the job-seeking category of the unemployed $\left(\chi^{2}=10.67, p=.06\right) .14$ per cent of all doctoral candidates from the Natural Sciences are seeking a job; this is five per cent higher than the average for all fields of study. Our findings correspond with national statistics, which demonstrate that while unemployment among doctorate holders is very low, one-third of unemployed doctorate holders obtained their degree in the Natural Sciences (Statistics Netherlands, 2011b).

The smallest difference in unemployment is between the Natural Sciences and Engineering and Technology (where 10 per cent of all doctoral recipients are unemployed but seeking a job). The largest difference can be found between the Natural Sciences and the Medical and Health Sciences, where only three per cent of doctoral recipients are unemployed and seeking employment. The higher proportion of unemployed, job-seeking graduates in the Natural Sciences is concentrated in one area of the Natural Sciences, namely the Biological Sciences. 11 of the 20 unemployed job seekers from the Natural Sciences are biologists. In no other field of study do we find such a significant proportion of unemployed job seekers. Again, this is not related to an overrepresentation of biologists in the Natural Sciences. Biologists represent 27 per cent of all candidates in the Natural Sciences (47 respondents), and 23 per cent of these Biologists (11 respondents) are unemployed at the time of the defence and seeking a job $\left(\chi^{2}=11.32, p=.001\right)$. While it would be intriguing to take an even closer look at this group of unemployed doctoral recipients in the Biological Sciences, given the small $\mathrm{n}$ this is not possible in a quantitative study. Qualitative analysis could offer some insights for further research.

Alongside $\mathrm{PhD}$ status and field of study, another possible characteristic related to unemployment could be academic performance. As discussed above, in the survey we take into account eight characteristics of academic performance focusing on conference papers, publications, external reports and the application of patents. Of these eight characteristics, only three are significantly and substantially related to being unemployed and seeking a job at the time of the defence (see Table 3; Wilks' Lambda $=8.446, \mathrm{p}=.01$ ). These include the number of papers (co)authored for presentation at regional, national or international conferences, the number of articles (co)authored and submitted to an international, refereed journal, and the number of articles (co)authored and accepted by an international, refereed journal. 
Table 3: Differences in Characteristics of Academic Performance

\begin{tabular}{|c|c|c|c|}
\hline Characteristics & Mean Employed $(\mathrm{n}=411)$ & $\begin{array}{l}\text { Mean Job Seekers } \\
(\mathrm{n}=44)\end{array}$ & F-test \\
\hline $\begin{array}{l}\text { (Co)authored conference } \\
\text { papers }\end{array}$ & 6.00 & 3.23 & $13.432 * *$ \\
\hline $\begin{array}{l}\text { Conference poster pres- } \\
\text { entations }\end{array}$ & 3.09 & 2.45 & 1.671 \\
\hline $\begin{array}{l}\text { (Co)authored articles } \\
\text { submitted to refereed } \\
\text { journals }\end{array}$ & 4.87 & 3.39 & $4.336^{*}$ \\
\hline $\begin{array}{l}\text { (Co)authored articles } \\
\text { accepted for publication } \\
\text { or published in refereed } \\
\text { journals }\end{array}$ & 4.44 & 2.68 & $5.863^{*}$ \\
\hline $\begin{array}{l}\text { (Co)authored books or } \\
\text { monographs accepted for } \\
\text { publication or published }\end{array}$ & 0.26 & 0.32 & 0.141 \\
\hline $\begin{array}{l}\text { (Co)authored book chap- } \\
\text { ters accepted for publica- } \\
\text { tion or published }\end{array}$ & 0.75 & 0.39 & 2.043 \\
\hline $\begin{array}{l}\text { (Co)authored external } \\
\text { reports accepted for pub- } \\
\text { lication or published }\end{array}$ & 1.09 & 0.23 & 3.013 \\
\hline $\begin{array}{l}\text { Attendance at profes- } \\
\text { sional meetings or con- } \\
\text { ferences }\end{array}$ & 0.81 & 0.84 & 0.210 \\
\hline
\end{tabular}

$* *$ Significant at the $\mathrm{p}<.001$ level.

* Significant at the $\mathrm{p}<.05$ level.

When testing for differences between the group of employed doctoral candidates and job-seeking doctoral candidates, in all three cases, job seekers score, on average, significantly lower than doctoral candidates currently employed at the time of the defence. Starting with the number of conference papers (co)authored by doctoral candidates, candidates who are employed by the time of the defence have (co)authored an average of six papers, whereas job seeking candidates have (co)authored an average of 3.2 papers $(\mathrm{F}(1,453)=13.432 ; \mathrm{p}<.001 ; \mathrm{n}=455)$. Next, looking at the number of submitted articles, employed doctoral candidates submitted an average of 4.9 articles for publication versus 3.4 articles by job seekers $(F(1,453)=4.336 ; p<.05 ; n=455)$. While it is possible that these results differ across the various $\mathrm{PhD}$ statuses, given the small sample size of job seekers, it is not possible to control for these differences. Lastly, candidates employed at the time of the defence had (co)authored, on average, 4.4 articles accepted for publication in an international, scientific journal versus 2.7 articles accepted for publication by the job-seeking group ( $F$ $(1,453)=5.863 ; \mathrm{p}<.05 ; \mathrm{n}=455)$.

\section{Conclusion}

In this article, we have taken a closer look at a small but important group among doctoral recipients in the Netherlands: the job seekers. Despite being a relatively small group (44 respondents), we are able to discern a number of important characteristics that define this group. Characteristics that matter most are the $\mathrm{PhD}$ status of the candidate, the field of study, and the performance during the $\mathrm{PhD}$ trajectory, in particular, the number of papers and articles produced. Doctoral candi- 
dates who are unemployed and seeking a job at the time of the defence have a lower number of (co)authored conference papers, articles submitted for publication, and articles accepted for publication. What does not matter is gender, age, nationality/citizenship, the expectations of the PhD candidate, perceived expectations of the graduate school or perceived expectations in regards to the supervisor, quality of supervision, or quality of the PhD programme.

Our findings suggest that unemployment among doctoral candidates is not random or evenly distributed. While this may point to specific anomalies in the Dutch case, e.g., the extreme amount of unemployed doctoral graduates in the Biological Sciences, our finding that academic performance is an important predictor of unemployment is more universal. This finding is even more important when considered in light of the push in academia for measurable academic output and performance. $\mathrm{PhD}$ graduates working to enter academia are increasingly expected to have a curriculum vitae that reflects strong academic performance, measured through such things as publications. This can make the already difficult situation of transitioning from the $\mathrm{PhD}$ to employment (Grover, 2007) even more challenging for those graduates lacking in these areas.

We do note a number of points for discussion. As mentioned earlier, we measure employment at the moment of the defence and expected employment six months beyond the defence, not within one to two years following the defence. Despite the structure of the Dutch system and the fact that 70 per cent of candidates intend to maintain their current position for at least the six months following graduation, we are unable to capture the employment situation beyond this point with our study. While we are unable to determine whether respondents in our study transition into stable employment, national statistics on doctorate holders in the Netherlands show that unemployment among doctorate holders only declines across time, suggesting an overwhelming majority find and maintain stable employment (Statistics Netherlands, 2011b). The point of measurement of employment in our study is, however, limited by being unable to capture employment positions that require a doctorate degree in hand (excluding $\mathrm{ABD}$ ), jobs which may be recruited for many months in advance. However, data such as ours that measures employment at the moment of defence can be used to consider the transition of doctoral candidates into the labour market, complementing existing research on the employment of doctoral recipients years beyond graduation. Another point for future research, one not addressed here, is the issue of underemployment or employment outside one's field. Underemployment, when an individual is employed below his or her educational level, or employment outside one's field, can in some ways be just as problematic as unemployment, as it suggests a mismatch between the doctoral education system and the labour market. National statistics reporting on the relationship between employment and the doctoral degree suggest that 19 per cent of all doctorate holders in the Netherlands are employed in a position unrelated to their degree, an issue deserving of more attention in future research.

In a final note, given economic changes, such as the global financial crisis, the employment of doctoral graduates is likely to be under pressure both within and outside academia. Within academia, budget cuts and funding pressures have made it difficult for many faculties to hire $\mathrm{PhD}$ graduates and postdoctoral funding opportunities are not always available. In the Netherlands, for example, the crisis has once again fuelled the debate about changing the structure of doctoral education by no longer offering doctoral candidates employment contracts with the university (as researchers) and instead to make doctoral candidates students at the university. Outside of academia, economic pressures can drive employers to seek less costly hires, which in some cases could make having a $\mathrm{PhD}$ a barrier to employment rather than an asset. To avoid conjecture, however, we suggest a research agenda that not only looks at the doctoral trajectories and employment of doctoral graduates but their unemployment as well, to investigate further the differences noted here. For example, what explains the difference in academic performance between the job seekers and the employed? Further research is needed to understand these relationships. 


\section{References}

Bleiklie, I., \& Høstaker, R. (2004). Modernizing research training-education and science policy between profession, discipline and academic institution. Higher Education Policy, 17(2), 221-236.

Brailsford, I. (2010). Motives and aspirations for doctoral study: Career, personal, and inter-personal factors in the decision to embark on a history PhD. International Journal of Doctoral Studies, 5, 15-27. Retrieved from http://ijds.org/Volume5/IJDSv5p015-027Brailsford283.pdf

Dotzler, R. J., \& Koppel, R. (1999). What sociologists do and where they do it. Sociological Practice, 1(1), 71-83.

Enders, J. (Ed.). (2001). Academic staff in Europe. Changing contexts and conditions. Westport, Connecticut: Greenwood Press.

Enders, J., \& de Weert, E. (2004). Science, training and career: Changing modes of knowledge production and labour markets. Higher Education Policy, 17(2), 135-152.

England, P., Allison, P., Li, S., Mark, N., Thompson, J., Budig, M. J., \& Sun, H. (2007). Why are some academic fields tipping toward female? The sex composition of U.S. fields of doctoral degree receipt, 1971-2002. Sociology of Education, 80(1), 23-42. doi: 10.1177/003804070708000102

Eurostat (Producer). (2006, 12 February 2011). Careers of doctorate holders. [Online data] Retrieved from http://epp.eurostat.ec.europa.eu/statistics_explained/index.php/Careers_of_doctorate_holders

EUROSTAT / UNESCO / OECD. (2006). Statistics on the careers of doctorate holders (CDH). Brussels: European Commission.

Gardner, S. K., \& Gopaul, B. (2012). The part-time doctoral student experience. International Journal of Doctoral Studies, 7, 63-78. Retrieved from http://ijds.org/Volume7/IJDSv7p063-078Gardner352.pdf

Grover, V. (2007). Successfully navigating the stages of doctoral study. International Journal of Doctoral Studies, 2, 9-21. Retrieved from http://www.ijds.org/Volume2/IJDSv2p009-021Grover21.pdf

Huisman, J., de Weert, E., \& Bartelse, J. (2002). Academic careers from a European perspective. The Journal of Higher Education, 73(1), 141-160.

Hulshof, M., Verrijt, A., \& Kruijthof, A. (1996). Promoveren en de arbeidsmarkt: ervaringen van de 'lost generation' (Doctoral Education and the Labour Market: experiences from the 'lost generation'.). (Beleidsgerichte Studies. Hoger Onderwijs en Wetenschappelijk Onderzoek (Policy-centred Studies. Higher Education and Scientific Research report no.43). The Hague: SDU.

Knobil, E. (1996). Doctoral education in the biomedical sciences: Back to the future? Academic Medicine, $71(8), 871-875$.

Kolfschooten, F. v. (2006, 18 May 2006). Fraude door anesthesist 'aannemelijk' ['Probable' fraud by anesthetist]. NRC Handelsblad. Retrieved from http://vorige.nrc.nl/wetenschap/article1684514.ece/fraude door anesthesist aannemelijk

Kolfschooten, F. v. (2007, 8 March 2007). Toch promotie na vermeende fraude [Defense still takes place following suspected fraud]. NRC Handelsblad. Retrieved from http://vorige.nrc.nl/thema archief oud/nieuwswetenschap/article1776887.ece

Lee, H.-f., Miozzo, M., \& Laredo, P. (2010). Career patterns and competences of PhDs in science and engineering in the knowledge economy: The case of graduates from a UK research-based university. Research Policy, 37(7), 869-881

Mastekaasa, A. (2005). Gender differences in educational attainment: The case of doctoral degrees in Norway. The British Journal of Sociology of Education, 26(3), 375-394.

Musselin, C. (2004). Towards a European academic labour market? Some lessons drawn from empirical studies on academic mobility. Higher Education, 48, 55-78. 
NRC. (2010). Gender differences at critical transitions in the careers of science, engineering, and mathematics faculty. Washington, DC: Committee on Gender Differences in the Careers of Science, Engineering, and Mathematics Faculty; Committee on Women in Science, Engineering, and Medicine; Committee on National Statistics; National Research Council

Organisation for Economic Co-operation and Development. (2011). Labour force statistics.

Scaffidi, A. K., \& Berman, J. E. (2011). A positive postdoctoral experience is related to quality supervision and career mentoring, collaborations, networking and a nurturing research environment. Higher Education, 62(6), 685-698.

Sclater, K., Rudd, E., Morrison, E., Picciano, J., \& Nerad, M. (2008). After the degree: Recent history PhDs weigh in on careers and graduate school. Seattle: Center for Innovation and Research in Graduate Education, Univserity of Washington.

Siegfried, J. J., \& Stock, W. A. (1999). The labor market for new Ph.D. economists. The Journal of Economic Perspectives, 13(3), 115-134.

Sonneveld, H., Yerkes, M. A., \& van de Schoot, R. (2010). PhD trajectories and labour market mobility. A survey of recent doctoral recipients at four universities in the Netherlands. Utrecht: IVLOS: Netherlands Centre for Graduate and Research Schools.

Statistics Netherlands. (2011a). Careers of doctorate holders (CDH) 2009. Heerlen: Centraal Bureau voor de Statistiek (Statistics Netherlands).

Statistics Netherlands. (2011b). Careers of doctorate holders (CDH) 2009 Data. from Centraal Bureau voor de Statistiek (Statistics Netherlands) http://www.cbs.nl/nl-NL/menu/themas/arbeid-socialezekerheid/publicaties/artikelen/archief/2011/2011-careers-doctorate-holders-art.htm

Stoneman, B. (1997). Whining by winners. American Demographics, 19(11), 34-35.

Tuckman, B. H., \& Tuckman, H. P. (1984). Unemployment among graduating Ph.D.'s: Do economic conditions matter? Research in Higher Education, 20(4), 385-398. doi: 10.1007/bf00974920

Yerkes, M., \& Visser, J. (2006). Women's preferences or delineated policies? The development of part-time work in the Netherlands, the UK and Germany. In J. Y. Boulin, M. Lallement, J. Messenger \& F. Michon (Eds.), Decent working time, new trends, new issues (pp. 235-262). Geneva: ILO.

\section{Biographies}

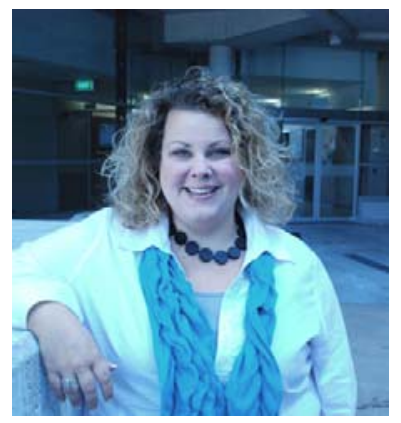

Mara Yerkes is Senior Research Fellow at the Institute for Social Science Research at the University of Queensland in Brisbane, Australia. Her current research focuses on the individual and organizational effects of paid parental leave policy in Australia. Yerkes has extensive research across a range of social policy issues, in particular labour market and family policy. More broadly, her research interests include comparative social policy and the welfare state, education and employment, the combination of work and care, industrial relations and gender and employment, in particular the prevalence of part-time work. Along with publications in Community, Work and Family; European Journal of Industrial Relations; Gender, Work and Organization; Journal of Comparative Social Welfare; Journal of Social Policy; Policy \& Politics; and Social Policy and Administration, Yerkes is the author of Transforming the Dutch Welfare State (Bristol: The Policy Press), and a co-editor of The Transformation of Solidarity. Changing Risks and the Future of the Welfare State (Amsterdam: Amsterdam University Press), both published in 2011. 


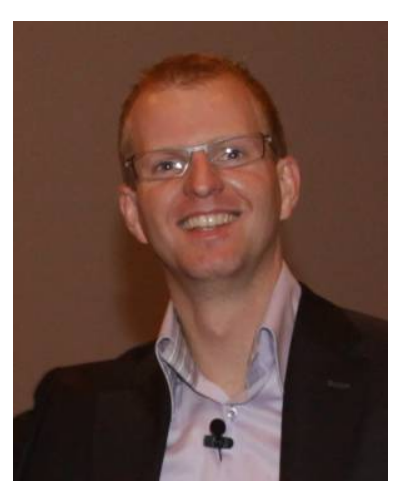

Rens van de Schoot graduated cum laude for the research master Development and Socialization of Children and Adolescents at Utrecht University in The Netherlands. He obtained his $\mathrm{PhD}$, also cum laude, about informative hypotheses and Bayesian statistics at the department of Methods and Statistics. Currently, he is Assistant Professor at Utrecht University and extra-ordinary professor at the North-West University in South Africa. Besides his research on how to directly evaluate expectations and the labour market position of $\mathrm{PhD}$ candidates, he collaborates with many developmental researchers. He is coeditor of the European Journal of Developmental Psychology, president of the young researchers union of the European Association of Developmental Psychology and he is vice-chair for the scientific committee of the Dutch Institute for Psychologists (NIP).

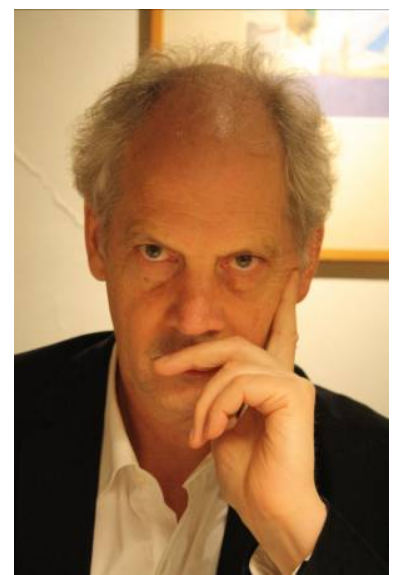

Hans Sonneveld is a sociologist by training, with a $\mathrm{PhD}$ in the social sciences \& science dynamics. From $1988-2006$ he was managing director of one of the first Dutch graduate schools, the Amsterdam School for social Science Research. In 1996, he published his book PhD supervisors, PhD students and the Academic Selection. In 2006, together with his colleague Heinze Oost († 2008), Hans Sonneveld founded the Netherlands Centre for Research and Graduate Schools, a meeting place for all those who work on the development of the Dutch $\mathrm{PhD}$ system. He has been investigating the careers of the $\mathrm{PhD}$ students who have defended their dissertation in the Netherlands, the interest of $\mathrm{PhD}$ students in contributing to secondary education and the completion and attrition rates of $\mathrm{PhD}$ subsidies by the Netherlands Organization for Scientific Research (NWO). At the individual level of teaching and coaching, Hans Sonneveld provides courses to PhD students (How to write your PhD Proposal). Hans also trains and supervises beginning and more experienced $\mathrm{PhD}$ supervisors in many fields, including Informatics, Psychology, Law, Arts, Meteorology, Physics and Educational Sciences. 